\title{
GREEN SUPPLY CHAIN MANAGEMENT PRACTICES IN FOOD RETAILING
}

\section{Kristina Petljak *}

\begin{abstract}
Increasing concern about environmental and social issues in food production and consumption has been spreading rapidly in Europe. From the corporate social responsibility (CSR) perspective, food and agribusiness companies are frequently subject to broad interests and there is an increasing need for them to respond to the sustainability challenges. Companies in the food sector are facing rapid changes due to the growing concern and raising awareness among consumers of traceability in the food supply chain, the origin of raw materials and food safety, environmental impacts of products and processes, as well as other social issues, such as animal welfare. As customers, governments, nongovernmental organizations (NGOs), media and wider society are all demanding from companies to provide an open and well-substantiated account on how they operate, what their impact on society is, and how they are minimizing negative impacts and saving scarce natural resources. More recently, retailers have also increasingly begun to address environmental concerns on the store level, as well as in the supply chain. The purpose of this paper is to identify and provide an overview of environmental practices among food retailers, the ones which they are pursuing on the store level, as well as in the supply chain.
\end{abstract}

KEYWORDS: green supply chain management, green retailing, grocery retailing, food retailing, store level retailing.

\footnotetext{
Assistant Professor at Trade and International Business Department, Faculty of Economics and Business, University of Zagreb; kpetljak@efzg.hr
} 


\section{INTRODUCTION}

Market globalization, rising competition and increased emphasis on consumer orientation and experience represent only a few of many reasons why the interest in supply chain management is growing ${ }^{1}$. Supply chain management (SCM) has emerged as an interesting field of observation due to the complexity of supply activities, along with the need of managing and coordinating the relations among supply chain members with the final aim of working together to improve material flow, flow of information and other issues which often lead to unsatisfactory service delivery. An effective supply chain management is considered a key factor for building sustainable competitive advantage through improved inter- and intra-organizational relations that are in fact the flow and transformation of the product (goods) from the raw material to the final consumer. Competitive advantage will be achieved by those companies which control the costs in the value chain better than their competition and/or differentiate themselves with their products in the way that they provide their customers with a kind of combination of superior quality, service to the customer, variety of the products, unique presence on the market ${ }^{2}$.

Every form of business activity includes the use of natural resources, i.e. it has some kind of marginal or a considerable impact on the environment. The issues relating to the environmental protection and the consequences they bear globally, regionally and locally, are more and more evident and they induce many discussions regarding pollution. Environmental issues and the activities related to the change in the perspective towards the environment have a major direct impact on legislation of many countries. The new, ever stronger pressure in the form of requests and legal acts has been put on the companies that are often, regarding different business aspects, the main triggers of business activities with a negative impact on the environment. Performing business activities in line with environmental protection cannot be observed only on the level of a company, but rather other companies have to be considered as well, i.e. the members of the supply chain. The companies are faced with the request to ensure environmental acceptability of the products on their way from the raw material, through production and retail, and finally to the final consumer, which includes all members and activities of the supply chain. Increased awareness of the companies and other interest groups on the importance of environmental protection leads to the environmentally responsible supply chain management, i.e. to the integration of the environmental thinking within the traditional concept of supply chain management.

\footnotetext{
Webster, M.: Supply system structure, management and performance: a conceptual model, International Journal of Management Reviews, 4 (4), 2002, p. 354.
}

2 Shapiro, J.F.: Modeling the Supply Chain, Thomson Brooks/Cole, 2007 
Traditionally, the strength in the supply chain belonged to the producers, however, in the last twenty years, there has been a fundamental change and shift in relations within the supply chain, and the strength has been "transferred" from the production side to the retail side of the supply chain ${ }^{3}$. In the new strength constellation in the distribution channel, retail occupies the dominant position, which comes from the fact that it is the last link in the supply chain that has direct contact with the consumers, i.e. it connects the producers and the consumers. The answer to the challenges of the modern ways of doing business, the retailers seek in the members of their own supply chain and through the closer cooperation of all the chain members, they search for the possibilities of advancing their business operations ${ }^{4}$. Due to the changes in the role and significance of the retailers in the supply chain, there has been more, even though, yet insufficient, research on retail supply chain management ${ }^{5}$. Environmentally responsible business activity is not the goal a company can achieve on its own, but rather it requires the common effort of other members in the supply chain. Green business implies the existence of a key "player" that has the power in the supply chain and the motivation for the introduction of green initiatives into the supply chain, on the store level, as well as in the supply chains.

\section{GREEN SUPPLY CHAIN MANAGEMENT}

The overview of the existing scientific literature on green supply chain management (GSCM) provides us with the conclusion that there are inconsistencies in the definitions and that the GSCM terminology is still not uniform. Discrepancies in the terminology and different understanding of green supply chain management make it impossible to compare certain researches on the level of the research problem, in some cases even in the same sectors. For the purposes of different research studies, green supply chain management is defined from different perspectives, i.e. it is observed within the areas like the supply, operations, marketing, and logistics, etc. ${ }^{6}$

\footnotetext{
3 Randall, W. S., Gibson, B. J., Defee, C. C., Williams, B. D.: Retail supply chain management: key priorities and practices, International Journal of Logistics Management, 22 (3) 2011, p. 390.

4 Ganesan, S., George, M., Jap, S., Palmatier, R., Weitz, B.: Supply chain management and retailer performance: Emerging Trends, Issues, and Implications for Research and Practice, Journal of Retailing, 85 (1) 2009, p. 84.

5 Randall, W. S., Gibson, B. J., Defee, C. C., Williams, B. D.: Retail supply chain management: key priorities and practices, International Journal of Logistics Management, 22 (3) 2011, p. 392.

6 Zhu, Q., Sarkis, J.: Relationships between operational practices and performance among early adopters of green supply chain management practices in Chinese manufacturing enterprises, Journal of Operations Management, 22 (3) 2004, p. 267.
} 
The variability in the detailed literature review of green supply chain management is present due to the heterogeneity of ecologically responsible practices in the supply chain, which is not surprising since different business subjects in different sectors/industries have been observed. Thereby, next to the term GSCM, there is mostly the synonym of "environmental supply chain management "(ESCM), while since the year 2000, the term sustainable supply chain management (SSCM) has been in use more frequently. Moreover, GSCM is more often identified with $\mathrm{SSCM}^{7}$. However, it needs to be noted that SSCM, with considering economic and ecological component, also implies the societal, i.e. social component and ethical issues.

Upon analyzing the existing definitions, Srivastava points out that there is no unified or generally accepted definition of green supply chain management or even of the scope of reflection upon green supply chain ${ }^{8}$. Sarkis thinks that definitions of green supply chains differ in the way that some researchers consider green supply chain to be exclusively buying ecologically acceptable products from the supplier, while other authors assume a broader context, like the industrial eco-system ${ }^{9}$. Zhu and Sarkis are not surprised by the lack of consensus in defining green supply chain management since green supply chain management encompasses managing the supply chain and managing the environment. ${ }^{10}$ Both areas represent relatively new fields in science and in practice. Green supply chain management relates to the introduction of ecological thinking into the supply chain, i.e. into its management. Figure 1 shows that companies can use the environment to create value in the supply chain, i.e. to realize green supply chain management. Due to the influence that the processes in the supply chain have on the environment, green supply chain management has been attracting more and more attention of the practitioners, especially supply chain managers. ${ }^{11}$

\footnotetext{
7 Linton, J.D., Klassen, R., Jayaraman, V.: Sustainable supply chains: An introduction, Journal of Operations Management, 25 (6) 2007, p. 1075.

8 Srivastava, S. K.: Green supply-chain management: A state-of-the-art literature review, International Journal of Management Reviews, 9 (1) 2007, p. 54.

9 Sarkis, J.: Greening the Supply Chain, Springer, Germany, 2006.

10 Zhu, Q., Sarkis, J.: Relationships between operational practices and performance among early adopters of green suplly chain management practices in Chinese manufacturing enterprises, Journal of Operations Management, 22 (3) 2004, p. 267.

11 Lin, R.-J.: Using fuzzy DEMANTEL to evaluate the green supply chain management practices, Journal of Cleaner Production, 40 (February) 2013, p. 32.
} 
Figure 1. Importance of the environment in creating the supply chain value

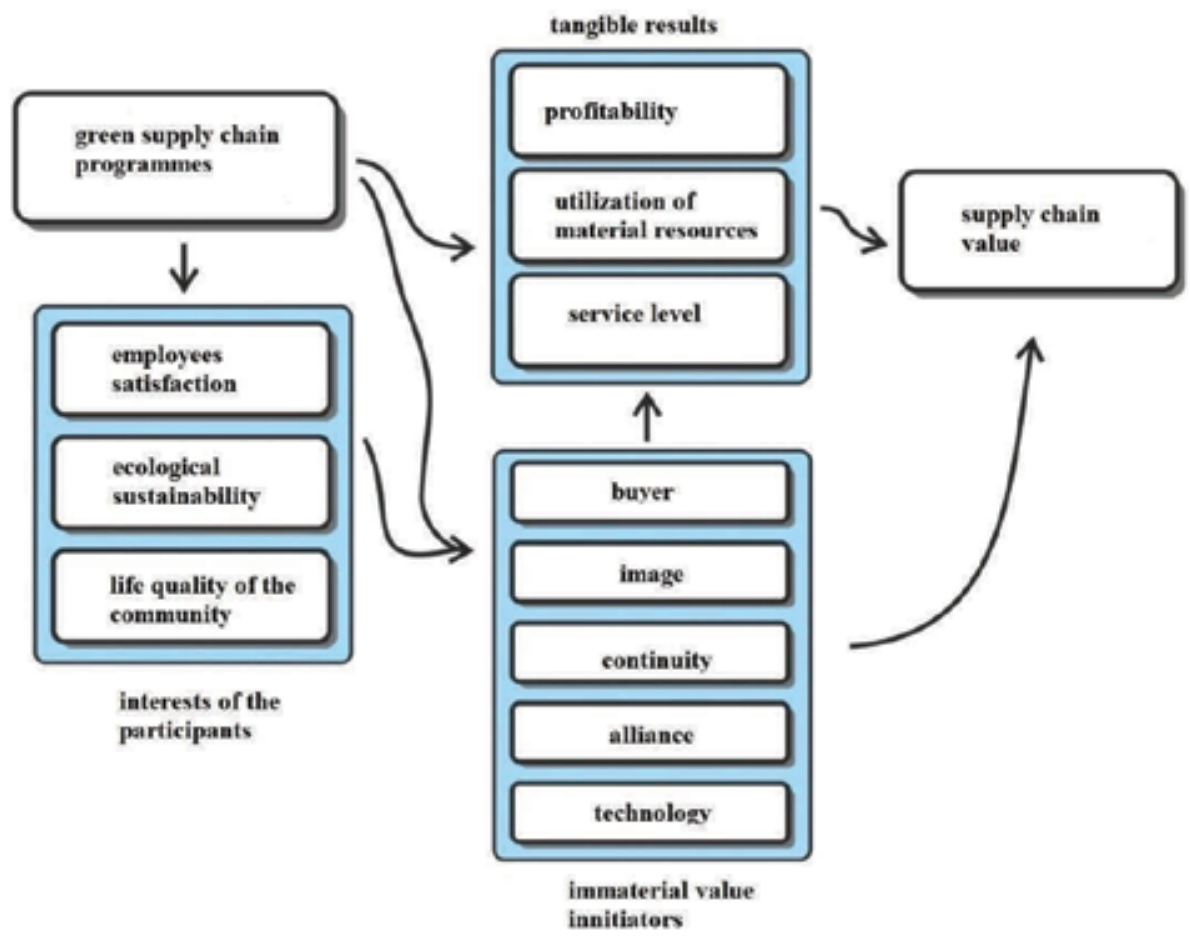

Source: SCC (2008), p. 4

Many authors see GSCM within only one function field ${ }^{12}$. Only later have the researchers focused on the research of ecologically responsible initiatives in the supply chain as a system, regarding the "upstream" and the "downstream" activities, i.e. taking account of the holistic improvement of ecological performances at all levels of the supply chain ${ }^{13}$

Min and Galle identify GSCM with green supply. ${ }^{14}$ They believe that green supply is one of the most effective ways of decreasing the impact of business subject activities on the environment and explain it by the use of green raw materials, i.e. activities that happen at the source of the supply chain. GSCM is also identified with environmentally conscious manufacturing (ECM), which relates to the im-

12 Sarkis, J.: How Green is the Supply Chain?, Practice and Research, Clark University, 1999, Worchester, MA

13 (Davies and Hochman, 2007).

14 Min, H., Galle, W. P.: Green purchasing practices of US firms, International Journal of Operations \& Production Management, 21 (9) 2001, p. 1222. 
plementation of production processes with the aim of minimizing or eliminating the waste, reducing energy consumption, better utilization of the materials and generally, better business operations influence on the safety of the environment. ${ }^{15}$

Handfield et al. ${ }^{16}$ consider green supply chain management as the application of the principle of managing the environment in an array of activities related to the customer order cycle (COC), including the design, supply, production, installation, packaging, logistics and distribution. Beamon ${ }^{17}$ states that the valorization of all the direct and eventual ecological effects of all the processes and products in the supply chain is the goal of GSCM. An entirely integrated supply chain, i.e. an "extended" supply chain (Figure 2) is the chain that comprises of all the elements of the traditional supply chain, but is "expanded", i.e. "extended" in a way to take into consideration the recycling of the product and the packaging, and also the reuse and/or operations of the reproduction in that semi-closed loop.

Figure 2. The extended supply chain

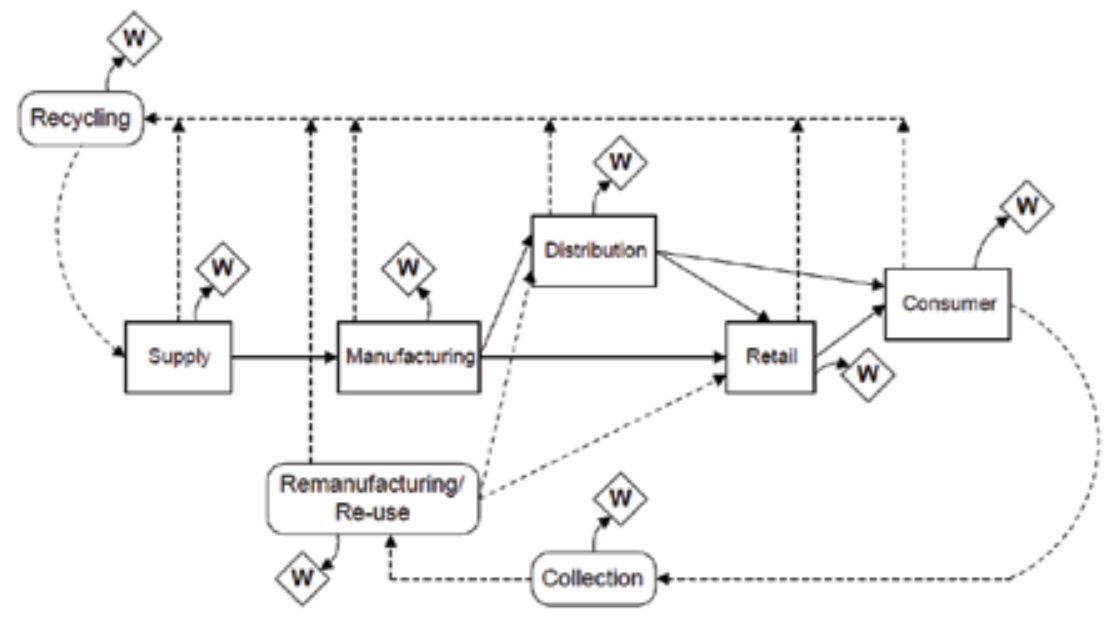

Legend:

Waste (or disposed) materia/s

Source: Beamon, B. M.: Designing the Green Supply Chain, Logistics Information Management, 12 (4) 1999, p. 336.

15 Lin, B., Jones, C. A., Hsieh, C.: Environmental practices and asessment: a process perspective, Industrial Management \& Data Systems, 101 (2) 2001, p. 71.

16 Handfield, R., Walton, S., Seegers, L. and Melnyk, S.: Green value chain practices in the furniture industry, Journal of Operations Management, 12 (5) 1997, p. 38-53.

17 Beamon, B. M.: Designing the Green Supply Chain, Logistics Information Management, 12 (4) 1999, p. 336. 
Hervani, Helms and Sarkis ${ }^{18}$ refer to GSCM as green supply, ecological production/management of the materials, ecologically conscious transport/marketing and reverse logistics (Figure 3).

\section{Figure 3. Graph of the green supply chain management}

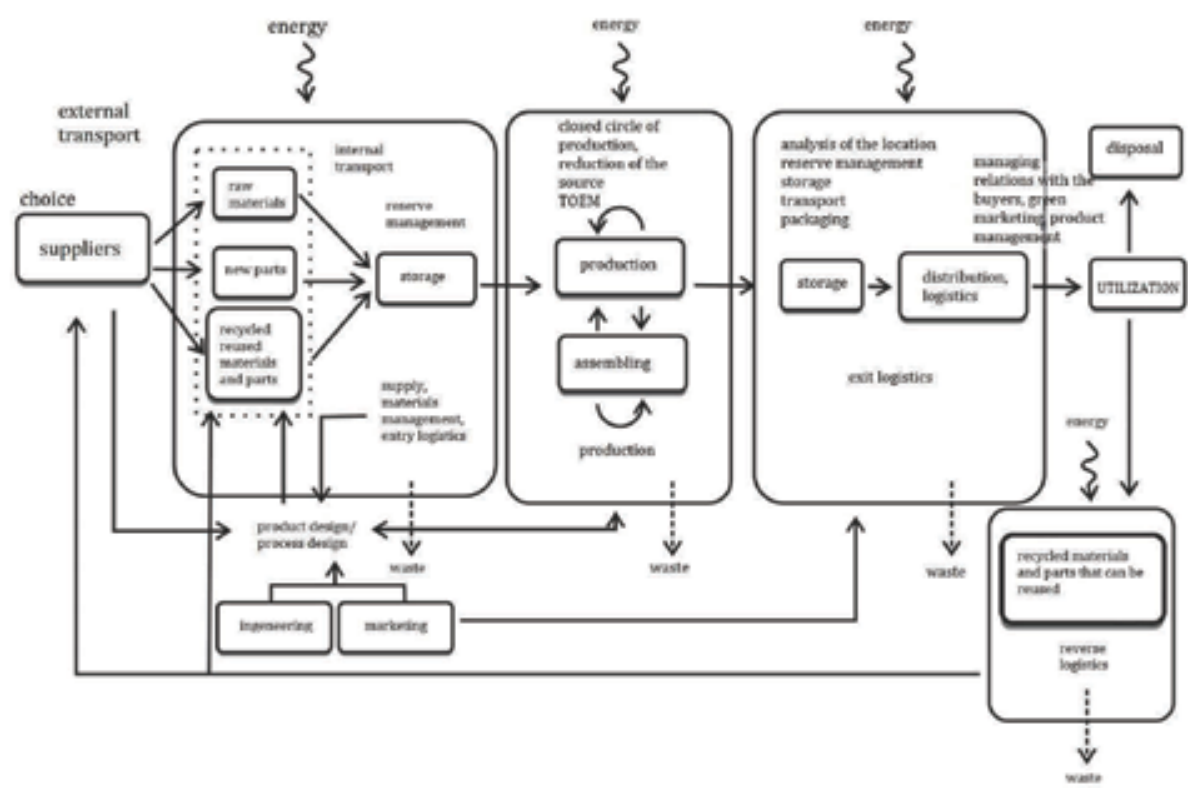

Source: Hervani, A. A., Helms, M. H., Sarkis, J.: Performance measurement for green supply chain management, Benchmarking: An International Journal, 12 (4) 2005, p. 335.

Wee et al. ${ }^{19}$ and Beamon ${ }^{20}$ support this definition and state that it is about integrating ecological responsibility into supply chain management. For Sheu, Chou and $\mathrm{Hu}$, green supply chain management is a kind of a combination of

18 Hervani, A. A., Helms, M. H., Sarkis, J.: Performance measurement for green supply chain management, Benchmarking: An International Journal, 12 (4) 2005, p. 335.

19 Wee, H.-M., Lee, M.-C., Yu, J. C. P., Wang, C. E.: Optimal replenishment policy for a deteriorating green product: Life cycle costing analysis, International Journal of Production Economics, 133 (2) 2011, p. 603-611.

20 Beamon, B. M.: Designing the Green Supply Chain, Logistics Information Management, 12 (4) 1999, p. 336. 
managing the supply chain of the producers and managing the reverse logistics chain of the used products. $^{21}$

Rao and Holt ${ }^{22}$ state that green supply chain management includes ecological initiatives into the business activities of an economic subject, regarding the entry-level logistics and production (the authors also call it the inside supply chain), the exit and reverse logistics, while Srivastava ${ }^{23}$ states that green supply chain management relates to the way innovations and supply chain policies respond to the need for a sustainable environment. GSCM is defined as the integration of ecologically conscious thinking into the supply chain, including the product design, material sourcing, production, distribution of the final product to the consumer and the end-of-life product management, and this view is also shared by Lau. ${ }^{24} \mathrm{H}^{\prime} \mathrm{Mida}$ and Lakhal ${ }^{25}$ evaluate green supply chain management with the life-cycle analysis (LCA). With the LCA method, they have evaluated the environmental influence of the activities along the entire supply chain. The life-cycle analysis of the food production supply chain is conducted by Mogensen et al. ${ }^{26}$ Figure 4, presents the influence of food production on the environment.

\footnotetext{
${ }^{21}$ Sheu, J.-B., Chou, Y.-H., Hu, C.-C.: An integrated logistics operational model for green supply chain management, Transportation Research Part E, 41 (4) 2005, p. 287-313.

22 Rao, P., Holt, D.: Do green supply chains lead to competitiveness and economic performance?, International Journal of Operations \& Production Management, 25 (9) 2005, str. 898916.

23 Srivastava, S. K.: Green supply-chain management: A state-of-the-art literature review, International Journal of Management Reviews, 9 (1) 2007, p. 54.

24 Lau, K. H.: Benchmarking green logistics performance with a composite index, Benchmarking: An International Journal, 18 (6) 2011, p. 873 - 896.

25 H'Mida, S., Lakhal, S.: A model for assessing the greenness effort in a product supply chain, International Journal of Global Environmental Issues, 7(1) 2007, p. 4-24.

26 Mogensen, L., Hermansen, J. E., Halberg, N., Dalgaard, R., Vis, J. C., Smith, B. G.: Life Cycle Assessment Across the Food Supply Chain, u: Baldwin, C.J. (ur.) Sustainability in the Food Industry, 2009
} 
Figure 4. The influence of food production on the environment - the life -cycle analysis

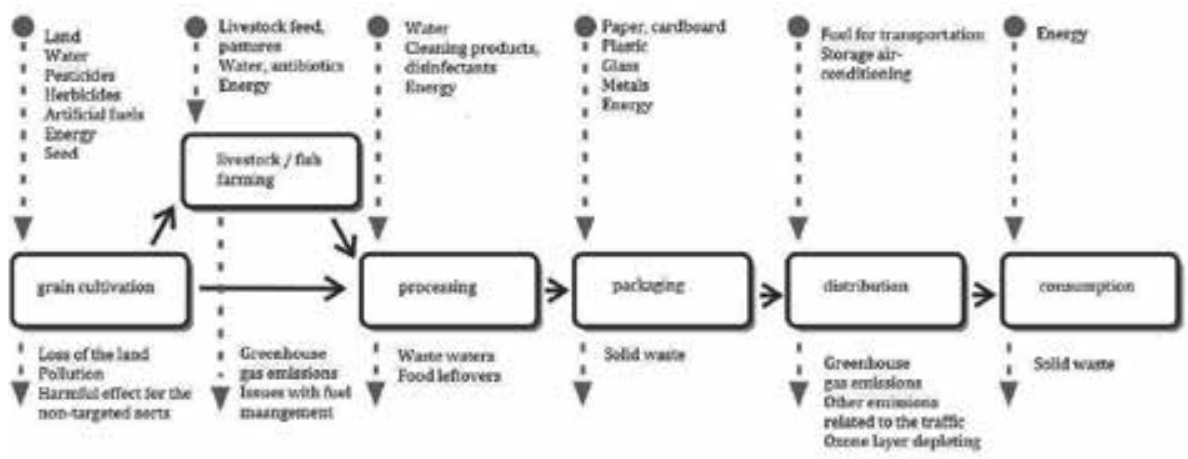

Source: Ministry of Environmental protection and Energy and Ministry of Construction and Spatial Planning of the Republic of Croatia (2004), [ http://www.mzoip.hr/doc/publikacije/ Odrziva_potrosnja_i_proizvodnja.pdf], accessed on May 7, 2019, p. 11

Srivastava $^{27}$ sees GSCM as the integration of environmental management (EM) and the process of decision-making on turning the resources into useful products. Lee and Klassen ${ }^{28}$ think of GSCM as being the plans and activities of a business subject that integrate ecological issues in the SCM with the aim of improving the ecological effects of the suppliers and the final buyers.

The scope of contemplating ecologically conscious supply chain management depends primarily on the issue and the goals of the research. ${ }^{29}$ Therefore, GSCM can be seen through the context of business processes in one company and business processes among companies. On the other hand, Davies and Hochman (2007) think that green supply chain management does not represent individual approach and the implementation of ecological activities in one company, but it rather calls for a holistic approach, i.e. improvement of ecological results at all levels of the supply chain. Vachon and Klaasen ${ }^{30}$ are

27 Srivastava, S. K.: Network design for reverse logistics, Omega, 36 (4) 2008, str. 535-548.

28 Lee, S., Klassen, R.: Drivers and enablers that foster environmental management capabilities in small-and medium-sized suppliers in supply chains, Production and Operations Management, 17 (6) 2008, str. 573-586.

29 Zhu, Q., Sarkis, J., Lai, K.-H.: Confirmation of a measurement model for green supply chain management practices implementation, International Journal of Production Economics, 111 (2) 2008, p. 261-273.

30 Vachon, S., Klassen, R. D.: Extending green practices across the supply chain: The impact of upstream and downstream integration, International Journal of Operations \& Production Management, 26 (7) 2006, pp. 795-821. 
focused on transaction issues in the green supply chain management and state that green supply chain management has to include at least two of the companies that deal with the trading.

El Saadany, Jaber and Bonney ${ }^{31}$ see green supply chain management as the reduction of energy consumption, the use of raw materials, generating waste and increasing the product recovery options (PRO). "Greening" usually refers to the functions in the supply chain like the production, supply, materials management, storage, reserves management, distribution, delivery, and transport logistics.

Green supply chain management integrates environmental protection and care in the inter-organizational practices of supply chain management, including reverse logistics. ${ }^{32}$ Parmigiani, Klassen and Russo ${ }^{33}$ define green supply chain management as the influence of the supply chains on the performances of environmental protection. Andiç, Yurt, Baltacioğlu ${ }^{34}$ state that green supply chain management implies minimization and eventual elimination of negative effects of the supply chain on the environment.

In the definitions of green supply chain management, the emphasis has been placed on the main features of the supply chain management, as the focus on the flows of the material, services and information, coordination of the activities inside or among the business subjects, focus on the interest groups and creating value (by increasing the profit or the market share), the focus on the efficiency of the supply chain with the aim of lowering the input and measuring the performances in the supply chain. ${ }^{35}$

While considering green supply chain management, the researchers mainly focus on the economic aspect, ecological activities and their influence on the interest groups (final buyers, consumers) and green supply chain management as a long-term activity. Srivastava ${ }^{36}$ classifies the papers from the field based on

31 El Saadany, A.M.A., Jaber, M.Y., Bonney, M.: Environmental performance measures for supply chains, Management Research Review, 34 (11) 2011, pp. 1202 - 1221.

32 Klaseen, R.D., Johnson, F.: The green supply chain, in: Understanding Supply Chains: Concepts, critiques and futures, (Ed.) New \& Westbrook, R., Oxford University Press, Oxford, 2004, pp. 229-251.

33 Parmigiani, A., Klassen, R.D., Russo, M.V.: Efficiency meets accountability: Performance implications of supply chain configuration, control and capabilities, Journal of Operations Management, 29 (3) 2011, pp. 212-223.

34 Andiç, E., Yurt, Ö., Baltacioğlu, T.: Green supply chains: Efforts and potential applications for the Turkish market, Resources, Conservation and Recycling, 58 2012, pp. 50-68.

35 Ahi, P., Searcy, C. (2013) A comparative literature analysis of definitions for green and sustainable supply chain management, Journal of Cleaner Production, 52 (1), pp. 329-341.

36 Srivastava, S. K.: Green supply-chain management: A state-of-the-art literature review, International Journal of Management Reviews, 9 (1) 2007, p. 54. 
the context of the topic; the papers where the accent is put on the importance of green supply chain management, the papers that emphasize ecologically responsible design and the papers that focus on ecologically conscious operations.

Until now, green supply chain management has been investigated through the research of ecological practices, like ecological supply, product handling, life-cycle analysis, and reverse logistics. Most of the existing researches focus on just one aspect, i.e. one activity in the green supply chain management. Hence, there is still a lack of integrative approach to the research of green supply chain management, deemed by the researchers as very important and necessary. ${ }^{37}$ The criticism of the existing research and the detailed guidelines for future research are presented concisely in Halldórsson and Arlbjørn. ${ }^{38}$

There are few authors that continually contribute to the development of green supply chain management, in Asia (Rao, Zhu), America (Sarkis) and Europe (McKinnon, Carter). From the listed authors, Sarkis has been conducting the researches on green supply chain management for the longest time, most thoroughly and most systematically. Sarkis moves forward in interdisciplinary research of green supply chain management as well, studies it and connects it with the organizational theory. ${ }^{39}$

New and Westbrook (Ascolfa, n/a) are dealing with the research of the approach to green supply chain management. According to the authors, transaction-oriented companies have a tendency to operate as independent "silo", thereby reducing the possibility of achieving ecologically conscious initiatives in the supply chain. Such companies put in considerable effort and resources in supply chains on limited managerial process control, i.e. they act retroactively. Companies that focus more on the network also take more care of the efficacy of the entire flow that delivers their product to the final buyers. Those companies, in fact, devote extra effort to shape green supply chain management and are proactive in many ecological initiatives.

In order to realize green supply chain management, it is necessary that all the members of the supply chain participate, i.e. integration of suppliers and final consumers is crucial. The integration of business activities and ecological responsibility in the activities that cross the boundaries of one business subject is

\footnotetext{
37 Zsidisin, G.A., Siferd, S.P. (2001) Environmental purchasing: a framework for theory development, European Journal of Purchasing \& Supply Management, 7 (1), pp. 61-73.

38 Halldórsson, Á., Arlbjorn, J.S. (2005) Research methodologies in supply chain management - what do we know?, u: Kotzab, H., Seuring, S., Müller, M., Reiner, G. (ur.) Research Methodologies in Supply Chain Management, Physica-Verlag, Heidelberg, pp. 107-122.

39 Sarkis, J., Zhu, Q., Lai, K.-h. (2011) An organizational theoretic review of green supply chain management literature, International Journal of Production Economics, 130 (1), pp. 1-15.
} 
not just good for economic practice but is also a prerequisite for the realization of a truly green supply chain management.

\section{DEVELOPMENT OF GREEN SUPPLY CHAIN MANAGEMENT}

The importance of environmental protection has been presented to the public with the publication of the book Silent Spring by Rachel Carson. This book bears the importance of having initiated the consideration of business activities and their implications on the environment. ${ }^{40}$ In the beginning, integration of business activities and ecological consciousness were considered to be conflicting, incompatible goals. ${ }^{41}$ The interest of the authors for green supply chain management over the last decade has increased, due to the rising public interest, and relatively poorly investigated the field of research. The rising number of scientific papers that deal with the problematic of green supply chain management can be traced to 1990s, with the appearance of the corporate environmental management (CEM), environmentally conscious manufacturing (ECM) and supply chain management ${ }^{42}$

\subsection{CONSIDERING ECOLOGICAL RESPONSIBILITY INSIDE THE BUSINESS SUBJECT}

The growing interest and the public awareness of the issue of environmental protection and the issues connected with the resource exploitation have led to more effective legislation on environmental management. Bearing in mind the before-mentioned changes, there has been the change in the perception of environmental responsibility among the companies in the sense that the "trend" of ecological responsibility is becoming a business imperative, especially for the production companies. ${ }^{43}$ For this reason, producers are considered leaders in understanding ecological responsibility and conducting the procedures for environmental protection, whether with the use of cleaner production or the

40 Sarkis, J., Zhu, Q., Lai, K.-h. (2011) An organizational theoretic review of green supply chain management literature, International Journal of Production Economics, 130 (1), pp. 1-15

${ }^{41}$ Lassar, W.M., Gonzalez, A. (2008) The State of Green Supply Chain Management - Survey Results [online]. Available from: http://business.fiu.edu/greensupplychain/pdf/StateofGreenSupplyChainMgmt-March2008.pdf

42 Zhu, Q., Sarkis, J. (2006) An inter-sectoral comparison of green supply chain management in China: drivers and practices, Journal of Cleaner Production, 14 (5), pp. 472-486.

43 van den Broek, F. (2010) Green Supply Chain Management, Marketing Tool or Revolution? [online]. Available from: http://www.nhtv.nl/fileadmin/user_upload/Documenten/PDF/Onderzoek_en_advies/Green_Supply_Chain_Management.pdf 
introduction of an environmental management system (EMS). The EMS is a system that is used by an organization to improve the relations towards the environment by reducing the bad influence, as the result of their activity with the help of the products life cycle and standard, like ISO 9000, ISO 14001.44 Petitions for evaluation of the influence on the environment marked the 1970s when informal groups started protesting and demanding that companies take more thought of the environment. ${ }^{45}$

The rising conscience of environmental protection was supported by the organization of the first conferences with the topics of environmental protection and the evaluation of the impact on the environment. The development of ecological responsibility dates back in 1972 (United Nations Conference on $\mathrm{Hu}$ man Environment) with the beginning of contemplating the possibility of economic development and industrialization without damaging the environment.

During the 1980s, principles of industrial ecology that are in the background of green supply chain management started to be taken under advisement. Industrial ecology is a systematically organized framework for many aspects of environmental management, and it sees the world as a natural system - a part of a local eco-system and global biosphere. Industrial ecology offers a thorough understanding of the value of modeling the industrial system on the eco-systems for achieving the sustainable ecological effect. The mission of industrial ecology is to evaluate the industrial system and to connect the industrial system with the humanistic ecological aspects. The idea is that the industry is seen in the way that it can adapt to the environment, i.e. it is necessary to optimize the raw materials, energy and the capital. Industrial ecology is the production component of sustainable development. ${ }^{46}$

In 1992, the Conference of the United Nations on the Environment and Development was held in Rio de Janeiro, which set the basis for further development of ecology in the world. ${ }^{47}$ Since then, the social responsibility of companies 'paradigm implies not only adhering to the regulations in the area of environmental protection, but also to the proactive initiatives of the leading companies in the matters of environmental responsibility. The companies are under big scrutiny of the public which demands that they follow ecologically responsible business practices. In 1990, first norms in the field of protection and preser-

\footnotetext{
44 Bolanča Z. (n/aa) Industrija i okoliš. [online]. Available from: http://okolis.grf.unizg.hr/ media/download_gallery/industrija_internet.pdf

45 Lazibat, T. (2009) Upravljanje kvalitetom, Znanstvena knjiga, Zagreb

46 Bolanča, Z. (n/a) Sustav upravljanja okolišem. [online]. Available from: http://okolis.grf. unizg.hr/media/download_gallery/sustav_upravljanja_okolisem.pdf

47 Lazibat, T. (2009) Upravljanje kvalitetom, Znanstvena knjiga, Zagreb
} 
vation of the environment are put forth, which served as the basis for drafting regulations for environmental management (EMAS), and which were accepted in the European Union in the first half of $1995 .{ }^{48}$

It is indisputable that business operations, i.e. financial performances of a company can directly depend on societal, i.e. ecological practices of the company. As time went by, there appeared examples of companies that accepted ecologically responsible practices and for that reason achieved economic benefit. The companies improved ecological performances due to the advantages of cleaner production and systemic managing the activities that influence the environment. Those activities exclusively relate to the activities within the business subject, and they are often financially challenging.

In the next period, the companies started the activities for prevention the environmental pollution. Although the activities are commonly performed inside the company, this is the first step out towards the analysis of the product life cycle with which companies try to assess the burden the product places on the environment, i.e. to identify the chances for ecological improvements, inside the company and outside the company, working together with the suppliers. ${ }^{49}$ Following the postulates of the analysis of the products life cycle, the companies are able to conceive a more fundamental approach to the issue in the way that they can systematically identify possible opportunities for ecological improvements in all the phases of the products life cycle. This approach is often called integrated supply chain management, while some authors, as has already been mentioned, identify the analysis of the products life cycle with ecologically responsible supply chain management.

\subsection{INTEGRATION OF ECOLOGICAL RESPONSIBILITY INTO THE SUPPLY CHAIN}

The earliest work that can be connected to what is today considered green supply chain management is the work by Ayres and Kneese (1969). In their work, they discuss water pollution, but also the warnings about the changes in the global climate due to the carbon and other greenhouse gases emission, so they are considered the forerunners of the ecologically responsible supply chain management thought. ${ }^{50}$ It is interesting that in the 1990 s, growing significance was given to

\footnotetext{
48 Lazibat, T. (2009) Upravljanje kvalitetom, Znanstvena knjiga, Zagreb

49 Vermeulen, W.J., Ras, P.J. (2006) The Challenge of Greening Global Product Chains: Meeting Both Ends, Sustainable Development, 14 (4), pp. 245-256.

50 Sarkis, J., Zhu, Q., Lai, K.-h. (2011) An organizational theoretic review of green supply chain management literature, International Journal of Production Economics, 130 (1), pp. 1-15
} 
ecological aspects of logistics and there was continual development of green logistics (GL) that studies the acceptability of logistical activities for the environment. Although it is hard to precisely determine when the investigation of "green" logistics began, the authors principally agree that the development can be attributed to the first publication of the article with the topic of ecological responsibility in a logistics journal. Murphy, Poist and Braunschwieg ${ }^{51}$ state that, sixty years ago, companies gave little attention to ecological degradation. Since 1995, there have been periodic publications in logistics literature of the papers on ecological responsibility of logistical activities. ${ }^{52}$ The research conducted by Aronsson and Brodin $^{53}$ gives an overview of the papers from ten logistics journals and they came to the conclusion that only 45 published articles (just $2.2 \%$ of the total number) deal with the issue of ecological responsibility of logistical activities.

McKinnon $^{54}$ divides "green" logistics into reducing the externalities related to the transport of the products, city logistics, reverse logistics, corporative strategies for environmental protection aiming at "green" legislative and green supply chain management. McKinnon is one of those authors who see logistics as the concept which is above the concept of supply chain management. Bearing in mind that in this work, we are leaning towards the vision that supply chain is the concept above logistics, then green supply chain management is the concept above the "green" logistics concept.

Several authors (Blanchard, 2006) think that green supply chain management has roots in the studies which investigated reverse logistics in the 1990s and that it is reverse logistics that contributed to further development and consideration of ecological responsibility in the supply chain. For example, Van Hoek ${ }^{55}$ thinks that the accent in green activities in logistics should be put on the reverse channel for waste matter and advocates expanding the research to managing the environment in the entire chain, from raw material to the service after the purchase. Namely, as early as at the beginning of the 20th century,

\footnotetext{
51 Murphy, P.R., Poist, R.F., Braunschwieg, C.D. (1996) Green logistics: comparative views of environmental progressives, moderates, and conservatives, Journal of Business Logistics, 17 (1), pp. 191-211.

52 Murphy, P.R., Poist, R.F. (2003) Green Perspectives and practices: a „,comparative logistics“ study, Supply Chain Management: An International Journal, 8 (2), pp. 122-131.

53 Aronsson, H., Brodin, M.H. (2006) The environmental impact of changing logistics structures, International Journal of Logistics Management,17(3), pp. $394-415$.

54 McKinnon, A. (2010) Environmental sustainability: a new priority for logistics managers, u: Green logistics: improving the environmental sustainability of logistics, ur. McKinnon, A., Cullinae, S., Browne, M., Whiteing, A., Kogan Page Limited, London, pp. 3-30.

55 Van Hoek, R. (1999) From reversed logistics to green supply chains, Supply Chain Management: An international journal, 4 (3), pp. 129-135.
} 
the authors recognized that the key to reducing the ecological influence of the company lies in managing the whole supply chain. ${ }^{56}$

Early development of the area of green supply chain management is based on conceptual development, i.e. the introduction of various concepts and practices related to green supply chain management. The first overview of the literature on green supply chain management dates back to the 1990s. With the development of this field, the research revolution happens, directed towards the development of the theory, testing the theory via empirical research, and the use of more advanced tools for modeling and evaluation of green supply chain management. ${ }^{57}$ Regarding the development of green supply chain management, the researchers use different mathematical and statistical tools to analyze green supply chain management. The most comprehensive overview, i.e. the classification of the used research methods brings Srivastava ${ }^{58}$ who divides them into empirical researches on green supply chain management and mathematical models and heuristics.

Legislative regulations, such as "Restriction of Hazardous Substances Directive" (RoHS) demand that companies widen their practices regarding environmental protection to their suppliers and buyers. As a result, companies are starting to adopt a systematic approach - green supply chain management -that integrates environmental protection into the supply chain. Zhu and Sarkis ${ }^{59}$ think that green supply chain management is generally accepted and practiced by proactive companies. With more pressure put by the legislative, big producers become more active in advocating environment-friendly practices in the supply chain, like participating in the voluntary programs. ${ }^{60}$

With the introduction of the European Commission Directives (EC Directive on Waste Electrical and Electronic Equipment (WEEE) (2002/96/EC), The Restriction of the Use of Certain Hazardous Substances (RoHS) in Electrical and Electronic Equipment (2002/95/EC), Restriction, Evaluation and Authori-

\footnotetext{
56 An, H.K., Amano, T., Utsumi, H., Matsui, S. (2008) A framework for Green Supply Chain Management complying with RoHS directive [online]. Available from: http://www.crrconference.org/downloads/2006kyunganamanoutsumimatsui.pdf

57 Sarkis, J., Zhu, Q., Lai, K.-h. (2011) An organizational theoretic review of green supply chain management literature, International Journal of Production Economics, 130 (1), pp. 1-15

58 Srivastava, S. K.: Green supply-chain management: A state-of-the-art literature review, International Journal of Management Reviews, 9 (1) 2007, p. 54.

59 Zhu, Q., Sarkis, J. (2004) Relationships between operational practices and performance among early adopters of green supply chain management practices in Chinese manufacturing enterprises, Journal of Operations Management, 22 (3), str. 265-289.

60 Zhu, Q., Geng, Y., Fujita, T., Hashimoto, S. (2010) Green supply chain management in leading manufacturers: Case studies in Japanese large companies, Management Research Review, 33 (4), str. 380-392.
} 
zation of Chemicals (REACH) (1907/2006/EC) and Packaging and Packaging Waste $(94 / 62 / \mathrm{EC})$, the attention of the legislation has been directed towards the producers and retailers with the aim of reducing the waste and better managing logistical operations ${ }^{61}$

Green supply chain management has emerged as an efficient tool for managing the environment and as the philosophy that was primarily adopted by many big producers. Therefore, it is not surprising that the literature abounds in the research on green supply chain management, and that the producers stand dominant in the focus of the researches, i.e. the method in which the producers manage the supply chain with ecological responsibility.

Green supply chain management represents an innovative idea. It is the way of achieving ecological acceptability, which is becoming more and more interesting to economic practice precisely due to extra care given to environmental issues, which has enticed the members of the supply chain to make the chain more eco-friendly. ${ }^{62}$ Furthermore, green supply chain management is gaining popularity in the business practice also due to the fact that many leading companies understand that consumers do not differentiate the practices of the company from their suppliers. Namely, the companies are often "accused" of non- environmentally friendly practices of the suppliers, so consumers identify those practices with the practices of the company, although the companies cannot be held legally responsible for the practices of their suppliers ${ }^{63}$

\section{CONCLUSION}

Regarding the position retailers hold in the chain creating value (connecting the supply and demand), they also have an important role in considering ecological acceptability of the business processes. Traditional measures for the competitive advantage of retailers like the price, quality, service and the vicinity of the retail store are becoming more and more "replaced" with an examination of the impact of retail activities on the environment and society in general. Food product retail sector is highly logistically intense, and food product retailers receive much criticism because of logistical activities that largely influence the environment.

\footnotetext{
${ }_{61}$ Cherrett, T., Maynard, S., McLeod, F., Hickford, A. (2010) Reverse logistics for the management of waste, u: Green logistics: improving the environmental sustainability of logistics, Kogan Page Limited, London

62 Cheng, J.-H., Yeh, C.-H., Tu, C.-W. (2008) Trust and knowledge sharing in green supply chains, Supply Chain Management: An International Journal, 13 (4), pp. 283-295.

63 Hall, J. (2000) Environmental supply chain dynamics, Journal of Cleaner Production, 8 (6), pp. 455-471.
} 
The changing market dynamics and a broad mix of the factors (like the rising consumer awareness, the pressure put by the government, the trade union and the investors, legislators, the development in information and communication technologies, media attention) are forcing the retailers to analyze the business processes and their impact on the environment and to act ecologically responsible, in stores and in the supply chains. Retailers have only recently started to pay more attention to business processes that include ecologically responsible activities into the very supply chain ${ }^{64}$. The literature mostly lists individual examples of the best world business practices, i.e. ecologically responsible activities that food product retailers conduct in their stores and the way in which they manage their supply chains with ecological responsibility.

\section{LITERATURE}

1. Ahi, P., Searcy, C.: A comparative literature analysis of definitions for green and sustainable supply chain management, Journal of Cleaner Production, 52 (1) 2013, pp. 329-341.

- DOI: https://doi.org/10.1016/j.jclepro.2013.02.018

2. An, H.K., Amano, T., Utsumi, H., Matsui, S. (2008) A framework for Green Supply Chain Management complying with RoHS directive, http://www.crrconference.org/downloads/2006kyunganamanoutsumimatsui.pdf, accessed on 5 May 2019

3. Andiç, E., Yurt, Ö., Baltacioğlu, T.: Green supply chains: Efforts and potential applications for the Turkish market, Resources, Conservation and Recycling, 58, 2012, pp. 50-68.

- DOI: https://doi.org/10.1016/j.resconrec.2011.10.008

4. Aronsson, H., Brodin, M.H.: The environmental impact of changing logistics structures, International Journal of Logistics Management, 17(3) 2016, pp. 394-415.

- DOI: https://doi.org/10.1108/09574090610717545

5. Beamon, B.M.: Designing the Green Supply Chain, Logistics Information Management, 12 (4) 1999, pp. 332-342.

- DOI: https://doi.org/10.1108/09576059910284159

6. Bolanča, Z. (n/a) Industrija i okoliš, http://okolis.grf.unizg.hr/media/download_ gallery/industrija_internet.pdf,accessed on 5 May 2019

7. Bolanča, Z. (n/a) Sustav upravljanja okolišem, http://okolis.grf.unizg.hr/media/ download_gallery/sustav_upravljanja_okolisem.pdf_accessed on 5 May 2019

${ }^{64}$ Petljak, K., Zulauf, K., Štulec, I., Seuring, S., Wagner, R: Green supply chain management in food retailing: survey-based evidence in Croatia, Supply Chain Management: An International Journal, 23(1) 2018, pp.1-15. 
8. Cheng, J.-H., Yeh, C.-H., Tu, C.-W.: Trust and knowledge sharing in green supply chains, Supply Chain Management: An International Journal, 13 (4) 2008, pp. 283-295.

- DOI: https://doi.org/10.1108/13598540810882170

9. Cherrett, T., Maynard, S., McLeod, F., Hickford, A.: Reverse logistics for the management of waste, $\mathrm{u}$ : Green logistics: improving the environmental sustainability of logistics, 2010, Kogan Page Limited, London

10. El Saadany, A.M.A., Jaber, M.Y., Bonney, M.: Environmental performance measures for supply chains, Management Research Review, 34 (11) 2011, pp. 1202 - 1221.

- DOI: https://doi.org/10.1108/01409171111178756

11. Ganesan, S., George, M., Jap, S., Palmatier, R., Weitz, B.: Supply chain management and retailer performance: Emerging Trends, Issues, and Implications for Research and Practice, Journal of Retailing, 85 (1) 2009, pp. 84-94.

- DOI: https://doi.org/10.1016/j.jretai.2008.12.001

12. Hall, J.: Environmental supply chain dynamics, Journal of Cleaner Production, 8 (6) 2000, pp. 455-471.

- DOI: https://doi.org/10.1016/S0959-6526(00)00013-5

13. Halldórsson, Á., Arlbjorn, J.S.: Research methodologies in supply chain management - what do we know?, in: Kotzab, H., Seuring, S., Müller, M., Reiner, G. (Eds) Research Methodologies in Supply Chain Management, Physica-Verlag, Heidelberg, 2005, pp. 107-122.

- DOI: https://doi.org/10.1007/3-7908-1636-1_8

14. Handfield, R., Walton, S., Seegers, L. and Melnyk, S.: Green value chain practices in the furniture industry, Journal of Operations Management, 12 (5) 1997, pp. 38-53.

15. Hervani, A. A., Helms, M. H., Sarkis, J.: Performance measurement for green supply chain management, Benchmarking: An International Journal, 12 (4) 2005, p. 335.

- DOI: https://doi.org/10.1108/14635770510609015

16. H'Mida, S., Lakhal, S.: A model for assessing the greenness effort in a product supply chain, International Journal of Global Environmental Issues, 7(1) 2007, pp. 4-24.

- DOI: https://doi.org/10.1504/IJGENVI.2007.012074

17. Klasseen, R.D., Johnson, F.: The green supply chain, in: Understanding Supply Chains: Concepts, critiques and futures, (Eds.) New i Westbrook, R., Oxford University Press, Oxford, 2004, pp. 229-251.

18. Lassar, W.M., Gonzalez, A.: The State of Green Supply Chain Management - Survey Results, 2008, http://business.fiu.edu/greensupplychain/pdf/StateofGreenSupplyChainMgmt-March2008.pdf,accessed on 5 May 2019 
19. Lau, K.H.: Benchmarking green logistics performance with a composite index, Benchmarking: An International Journal, 18 (6) 2011, pp. 873 - 896.

- DOI: https://doi.org/10.1108/14635771111180743

20. Lazibat, T. (2009) Upravljanje kvalitetom, Znanstvena knjiga, Zagreb

21. Lee, S., Klassen, R.: Drivers and enablers that foster environmental management capabilities in small- and medium-sized suppliers in supply chains, Production and Operations Management, 17 (6) 2008, pp. 573-586.

- DOI: https://doi.org/10.3401/poms.1080.0063

22. Lin, B., Jones, C. A., Hsieh, C.: Environmental practices and assessment: a process perspective, Industrial Management \& Data Systems, 101 (2) 2001, p. 71-79. - DOI: https://doi.org/10.1108/02635570110384348

23. Lin, R.-J.: Using fuzzy DEMANTEL to evaluate the green supply chain management practices, Journal of Cleaner Production, 40 (February) 2013, p. 32.

- DOI: https://doi.org/10.1016/j.jclepro.2011.06.010

24. Linton, J.D., Klassen, R., Jayaraman, V.: Sustainable supply chains: An introduction, Journal of Operations Management, 25 (6) 2007, p. 1075-1082.

- DOI: https://doi.org/10.1016/j.jom.2007.01.012

25. McKinnon, A.: Environmental sustainability: a new priority for logistics managers, in: Green logistics: improving the environmental sustainability of logistics, Eds. McKinnon, A., Cullinae, S., Browne, M., Whiteing, A., Kogan Page Limited, London, 2010, pp. 3-30.

26. Min, H., Galle, W.P.: Green purchasing practices of US firms, International Journal of Operations \& Production Management, 21 (9) 2001, pp. 1222-1238.

- DOI: https://doi.org/10.1108/EUM0000000005923

27. Mogensen, L., Hermansen, J.E., Halberg, N., Dalgaard, R., Vis, J.C., Smith, B.G.: Life Cycle Assessment Across the Food Supply Chain, in: Baldwin, C.J. (Ed.) Sustainability in the Food Industry, 2009

28. Murphy, P.R., Poist, R.F., Braunschwieg, C.D.: Green logistics: comparative views of environmental progressives, moderates and conservatives, Journal of Business Logistics, 17 (1) 1996, pp. 191-211.

29. Murphy, P.R., Poist, R.F.: Green Perspectives and practices: a comparative logistics study, Supply Chain Management: An International Journal, 8 (2) 2003, pp. 122-131. - DOI: https://doi.org/10.1108/13598540310468724

30. Parmigiani, A., Klassen, R.D., Russo, M.V.: Efficiency meets accountability: Performance implications of supply chain configuration, control and capabilities, Journal of Operations Management, 29 (3) 2011, pp. 212-223.

- DOI: https://doi.org/10.1016/j.jom.2011.01.001

31. Petljak, K., Zulauf, K., Štulec, I., Seuring, S., Wagner, R: Green supply chain management in food retailing: survey-based evidence in Croatia, Supply Chain Management: An International Journal, 23(1) 2018, pp.1-15.

- DOI: https://doi.org/10.1108/SCM-04-2017-0133 
32. Randall, W. S., Gibson, B. J., Defee, C. C., Williams, B. D.: Retail supply chain management: key priorities and practices, International Journal of Logistics Management, 22 (3) 2011, pp. 390-402.

- DOI: https://doi.org/10.1108/09574091111181381

33. Rao, P., Holt, D.: Do green supply chains lead to competitiveness and economic performance?, International Journal of Operations \& Production Management, 25 (9) 2005, pp. 898-916.

- DOI: https://doi.org/10.1108/01443570510613956

34. Sarkis, J., Zhu, Q., Lai, K.-h.: An organizational theoretic review of green supply chain management literature, International Journal of Production Economics, 130 (1) 2011, pp. 1-15.

- DOI: https://doi.org/10.1016/j.ijpe.2010.11.010

35. Sarkis, J.: Greening the Supply Chain, Springer, Germany, 2006.

- DOI: https://doi.org/10.1007/1-84628-299-3

36. Sarkis, J.: How Green is the Supply Chain?, Practice and Research, Clark University, 1999, Worchester, MA

- DOI: https://doi.org/10.2139/ssrn.956620

37. Shapiro, J. F.: Modeling the Supply Chain, Thomson Brooks/Cole, 2007

38. Sheu, J.-B., Chou, Y.-H., Hu, C.-C.: An integrated logistics operational model for green supply chain management, Transportation Research Part E, 41 (4) 2005, pp. 287-313.

- DOI: https://doi.org/10.1016/j.tre.2004.07.001

39. Srivastava, S.K.: Green supply-chain management: A state-of-the-art literature review, International Journal of Management Reviews, 9 (1) 2007, pp. 54-80.

- DOI: https://doi.org/10.1111/j.1468-2370.2007.00202.x

40. Srivastava, S.K.: Network design for reverse logistics, Omega, 36 (4) 2008, pp. 535-548.

- DOI: https://doi.org/10.1016/j.omega.2006.11.012

41. Vachon, S., Klassen, R. D.: Extending green practices across the supply chain: The impact of upstream and downstream integration, International Journal of Operations \& Production Management, 26 (7) 2006, pp. 795-821.

- DOI: https://doi.org/10.1108/01443570610672248

42. van den Broek, F.: Green Supply Chain Management, Marketing Tool or Revolution?, 2010, http://www.nhtv.nl/fileadmin/user_upload/Documenten/PDF/Onderzoek_en_advies/Green_Supply_Chain_Management.pdf

43. Van Hoek, R.: From reversed logistics to green supply chains, Supply Chain Management: An international journal, 4 (3) 1999, pp. 129-135.

- DOI: https://doi.org/10.1108/13598549910279576 
44. Vermeulen, W.J., Ras, P.J.: The Challenge of Greening Global Product Chains: Meeting Both Ends, Sustainable Development, 14 (4) 2006, pp. 245-256.

- DOI: https://doi.org/10.1002/sd.270

45. Webster, M.: Supply system structure, management and performance: a conceptual model, International Journal of Management Reviews, 4 (4), 2002, p. 353-369.

- DOI: https://doi.org/10.1111/1468-2370.00092

46. Wee, H.-M., Lee, M.-C., Yu, J.C.P., Wang, C.E.: Optimal replenishment policy for a deteriorating green product: Life cycle costing analysis, International Journal of Production Economics, 133 (2) 2011, pp. 603-611.

- DOI: https://doi.org/10.1016/j.ijpe.2011.05.001

47. Zhu, Q., Geng, Y., Fujita, T., Hashimoto, S.: Green supply chain management in leading manufacturers: Case studies in Japanese large companies, Management Research Review, 33 (4) 2010, pp. 380-392.

- DOI: https://doi.org/10.1108/01409171011030471

48. Zhu, Q., Sarkis, J., Lai, K.-H.: Confirmation of a measurement model for green supply chain management practices implementation, International Journal of Production Economics, 111 (2) 2008, pp. 261-273.

- DOI: https://doi.org/10.1016/j.ijpe.2006.11.029

49. Zhu, Q., Sarkis, J.: An inter-sectorial comparison of green supply chain management in China: drivers and practices, Journal of Cleaner Production, 14 (5) 2006, pp. 472-486.

- DOI: https://doi.org/10.1016/j.jclepro.2005.01.003

50. Zhu, Q., Sarkis, J.: Relationships between operational practices and performance among early adopters of green supply chain management practices in Chinese manufacturing enterprises, Journal of Operations Management, 22 (3) 2004, pp. 265-289.

- DOI: https://doi.org/10.1016/j.jom.2004.01.005

51. Zsidisin, G.A., Siferd, S.P.: Environmental purchasing: a framework for theory development, European Journal of Purchasing \& Supply Management, 7 (1) 2011, pp. 61-73.

- DOI: https://doi.org/10.1016/S0969-7012(00)00007-1

\section{ONLINE SOURCES:}

1. http://www.crrconference.org/downloads/2006kyunganamanoutsumimatsui.pdf, accessed on 5 May 2019

2. http://www.nhtv.nl/fileadmin/user_upload/Documenten/PDF/Onderzoek_en_advies/Green_Supply_Chain_Management.pdf_accessed on 5 May 2019 